\title{
Historical Perspectives on Precarious Work: The Cases of Egypt and India under British Imperialism
}

\author{
Peter Bent, University of Massachusetts (Amherst), United States
}

\begin{abstract}
The concept of precarious work is used by social scientists to describe work that is "uncertain, unpredictable, and risky from the point of view of the worker" (Kalleberg, 2009: 2). This paper argues that such work can take a variety of forms, beyond those seen in the transition from the stable post-WWII era to the neo-liberal era in the West. Egypt and India offer instructive case studies. Industrialisation (or lack thereof) in Egypt and India has been thoroughly documented by others. The purpose of this paper is to argue that these developments can be seen as the emergence of precarious, industrial working arrangements. This framework is useful for demonstrating that precarious work has come along with industrial development in a range of countries during different time periods. In this light, the stable employment arrangements characteristic of the post-war West were an anomaly. The global economic and social history of industrialisation is characterised by precarious working arrangements, as seen in colonial-era Egypt and India.
\end{abstract}

\section{KEYWORDS}

precarious labour; industrialisation; Egypt; India

In his 2008 presidential address to the American Sociological Association, Arne L. Kalleberg (2009: 2) argued that for "several decades, both in the United States and worldwide, social, economic, and political forces have aligned to make work more precarious". He goes on to offer a general definition of precarious work: "employment that is uncertain, unpredictable, and risky from the point of view of the worker" (Kalleberg, 2009: 2). To make his case, Kalleberg presents data showing how, in recent decades, millions of Americans have been compelled to leave their jobs involuntarily, while home mortgage foreclosures and personal bankruptcy filings have also increased. More broadly, the stresses of precarious work are associated with problems beyond the workplace, with repercussions extending through social and political spheres. These developments contrast starkly with the "golden age" of capitalism during the couple of decades following World War II. The goal in this paper, however, is to argue that precarious work has in fact been characteristic of employment relations across a range of historical time periods and countries. In this sense, "employment that is uncertain, unpredictable, and risky from the point of view of the worker" is seen as being a normal part of capitalist development. The relative stability and security of employment in the West post-WWII, then, was an anomaly. To make this case, I focus on the industrialisation that occurred in Egypt and India under British imperial rule. The employment opportunities that arose with these developments were precarious, following Kalleberg's definition.

To be sure, Kalleberg (2009: 3-4) recognises that work has often been precarious, even in the 
United States. Once factories were developed employers could directly control when and how workers worked, adding new layers of insecurity to employment. Macro-level factors, such as seasonal and cyclic factors, helped determine employment security across sectors. For instance, American textile and glass workers at the beginning of the twentieth century could only expect to be employed for three-quarters of a year, and in 1909 the average employment levels in industrial occupations fluctuated by 14 per cent, and by 45 per cent in the automobile industry (Jacoby, 2004: 16-17). Workers eventually unionised and fought for more stable working arrangements. By the end of War World II, American workers had better access to more stable jobs. However, this time period (1940s to 1970s) is best seen as being uncharacteristic of industrial development in general. I add to Kalleberg's historical framework the experiences of working in industrialising Egypt and India under British rule. Expanding the historical and geographical scope of when and where work has been precarious highlights the degree to which the post-WWII period of relatively stable working conditions in the West was an anomaly.

Another way to frame the study of labour in both core and peripheral countries, historically and in modern times, is to focus on "informal" labour. ${ }^{1}$ The process of informalisation has been defined as the "casualization of, or making casual, once formalized relations, such as employment relations" (Sassen, 1994: 155, quoted in Broad, 2000: 24; see also Van der Linden, 2003: 198). While this process is an important part of the historical development (and breakdown) of labour markets around the world, the focus in this paper on precarious work points to a slightly different, though related, process. In modern advanced economies, labour has become more precarious (and informal, following Sassen's definition) as relatively stable employment relations have declined. In the historical cases discussed below, labour became more precarious through the process of industrialisation, to the extent that it occurred. Thus this paper argues that precarious work has developed along with the rise of industrial work, and not only through the latter's demise. Informalisation is part of this process in both the modern and historical contexts, but precariousness as a framework points toward changes in employment relations as they exist formally, rather than focusing on informal labour. In the historical cases, work could become precarious even as it moved from being informal to formal with the rise of modern industry.

Kalleberg's expanded framework of what constitutes precarious work helps clarify what was precarious about new working arrangements in colonial Egypt and India. The following five categories provide a benchmark with which to compare the situations facing workers during these times of structural economic and social change (Kalleberg, 2009: 6-8). First there is the decline in attachment to employers. Second is the increase in long-term unemployment. Third is growth in perceived job insecurity. Fourth is the growth of non-standard work arrangements and contingent work. Finally, there is the increase in risk-shifting from employers to employees. Kalleberg finds that these five features characterise precarious work in the post-Bretton Woods West. These features of modern precarious work are also comparable to the types of employment situations that came into being in colonial Egypt and India. These case studies expand the discussion of when and where precarious work developed.

To make this case for Egypt, I reframe traditional accounts of the history of Egypt's

1 A wide range of historical and contemporary examples of the process of the "informalisation" of labour are discussed in the volume edited by Tabak and Crichlow (2000). See Agarwala (2013) for an in-depth study of the politics of informal labour in modern India. 
industrialisation (and lack thereof) to highlight the aspects of this process that fit Kalleberg's framework. For the Indian case, I undertake a similar reframing of the existing literature, especially the extensive debates surrounding deindustrialisation in colonial India. There is more primary source data for the Indian case than the Egyptian case, since it was such a prominent part of the British Empire and was under British rule for longer.

\section{The Development of Precarious Work in Colonial Egypt}

The most notable changes that took place in the Egyptian economy during the nineteenth century were connected to the production of cotton. Even the nascent industrialisation that occurred at this time was often directly tied to the growth and processing of cotton for export. Cotton transformed agriculture and industry, as detailed below, during its spread from Lower to Upper Egypt. To the extent that industry existed it was mostly for local consumption, though cities such as Cairo had larger-scale production for export. Textile production was already the dominant industry at the beginning of the nineteenth century, with cotton, flax, silk and wool textiles produced for export. When the French came to Egypt in 1798, there were over 2000 textile workers in al-Mahalla alKubra, 600 textile workers in Beni Suef, and 250 textile workers in Qena (Owen, 1969: 12-13). While the main Egyptian industries at this time were based on textile production, Egyptian industry also included the production of seed oils, sugar products, bricks, pottery and simple tools.

When the French arrived, "Administratively the old social forms remained; masters, journeymen, and apprentices being grouped into craft organisations or guilds under the shaykh [sic] or headman, with rigid rules about who might open a factory, what products might be made, and at what price they could be sold" (Owen, 1969: 13; see also Baer, 1964). These structures began to change under Muhammad Ali's rule, when Egypt's first stages of industrialisation occurred (Panza and Williamson, 2013). When Muhammad Ali consolidated his power over Egypt after the death of the Mamluk leader Alfi Bey and the defeat of a British expedition in 1807, he needed to raise revenues to support his armies. Worried that relying too heavily on levies would dampen economic activity and incite revolt, he experimented with new ways of raising government revenues. To this end, he raised and extended land taxes, rooted out corruption, established a government monopoly over grain exports, and took measures to industrialise the Egyptian economy.

Muhammad Ali undertook a top-down approach to industrialisation. He closed cotton textile workshops and abolished weavers' corporations. In their place he built looms in governmentcontrolled factories and compelled the previously free masters and artisans to work in his factories as employees. This changed work relations in ways similar to the development of factories in Britain and the United States (Marx, 1976: 492-639). The industrialisation of Egypt proceeded from these developments. All textile production, not just cotton cloth, fell under the government monopoly. "Village weavers were strictly supervised, their goods purchased at fixed price, and a stamp affixed to every piece produced without which no cloth could be sold" (Owen, 1969: 23). European machinery was imported and new textile factories were built in the Khurunfish and Bulaq districts of Cairo. By 1820 three more mills, a foundry, two dyeing establishments and a bleaching factory were built and running in Bulaq. Through industrialisation Muhammad Ali could secure some degree of economic independence from Europe, as well as attempt to "revive Egypt by subjecting it to modern 'civilizing' influences" (Owen, 1969: 24).

These initial efforts to industrialise Egypt had far-reaching impacts on Egyptian workers and 
peasants alike, as the segments of the population which were brought into these new factories faced unforgiving work arrangements, while those peasants who remained in their villages had their lives changed by the production of cotton. As cotton cultivation became widely promoted, "peasants lost much of their former freedom and were often the victims of fraudulent practices by government administrators in the measurement and valuation of their crops; townspeople were forcibly conscripted for work in the factories; [and] artisans left their jobs rather than submit to the new rules which governed the practice of their trade" (Owen, 1969: 25). Thus most Egyptians who engaged in industrial work were in low-level, precarious working arrangements, even before the British occupation.

Panza and Williamson (2013) argue convincingly that Muhammad Ali was successful at bringing modern industry to Egypt. However, Muhammad Ali's industrialisation programmes did not result in the prolonged, widespread industrialisation of the Egyptian economy or society, though under his successors further progress toward modernisation occurred, mainly through the expansion of canal networks, railways and telegraphs. And while Ali "opened some technical schools and sent Egyptian students for training in Europe, ... his policies were not pursued long enough for any native class of skilled artisans, managers or entrepreneurs to be formed" (Mansfield, 1971: 107).

The next stage of industrial development in Egypt took place under mainly British oversight. Lord Cromer, as British Controller-General of Egypt, actively discouraged the development of a domestic Egyptian cotton textile industry. The British encouraged cotton production such that the main beneficiaries were the cotton mill owners in Britain (Mansfield, 1971). Cotton production in Egypt was often directly financed by British cotton merchants (Owen, 1969: 222). The British also oversaw the development of some cotton-related industrial development in Egypt itself, but these were exceptions to the general British goal of discouraging industrialisation in Egypt during the late nineteenth century (Mansfield, 1971: 108).

Overall, from the initial industrial developments promoted by Muhammad Ali through the efforts that took place under British occupation, Egyptian industry was closely linked with agricultural developments, especially the increasingly widespread cultivation of cotton. Some mention was made above of the effects that these developments had on the Egyptian peasantry. But what about the people who actually worked in the factories? Workers' experiences of industrialisation, especially under British occupation, was defined by the development of particularly precarious working arrangements.

Goldberg (1983) analyses the nuances of class identities and working-class politics during the first half of the twentieth century, from the beginning of the Great Depression through the mid1950s. His findings offer useful insights into the precarious working arrangements Egyptians faced. Especially relevant for this purpose is the account of workers in the sugar industry. While cotton dominated agricultural activity and the early industrialisation efforts, sugar was the first mass production industry in Egypt (Goldberg, 1983: 251). In 1912, 14426 Egyptians worked as day labourers in sugar factories, while 390 Egyptians were employed in these factories as skilled or semiskilled workers, along with 267 European professionals or managers (Goldberg, 1983: 256). While cotton could be sent to Britain after minimal processing, sugarcane had to be processed locally soon after harvesting. This fact shaped the working arrangements of Egyptian peasants, first under Muhammad Ali's rule, and then under the British.

Egyptians employed in early twentieth-century sugar factories were "peasants in workers' clothes" (Goldberg, 1983: 249). They tended to live in villages near the mills, and worked in the mills 
at harvest time, in order to process the sugarcane as it came in. ${ }^{2}$ But sugarcane planting overlapped with the harvesting period in late winter. This meant that workers were needed in the sugar factories just as they were also needed in the villages to help with the harvest and to plant next year's crop. As a result of these structural features of the sugar industry, workers had relatively strong bargaining power; they could afford to strike for better working conditions, because they had agricultural work in their villages to fall back on. Still, that thousands of Egyptians left their farms to seek industrial employment at this time suggests that they desired wage income beyond that which they could earn through farming. But the working conditions in sugar factories were especially precarious, as these jobs were limited and defined by the seasons.

The first protests against the twelve-hour workdays and poor conditions in these factories was recorded in 1910, in Hawamdieh outside Cairo. In one such case,

there was considerable unfocused hostility among the local work-force directed at the [Hawamdieh sugar] mill and specifically at the mill as a physical presence. The men in charge of the mill as an organizational system found it hard to understand why that hostility would suddenly flare up against the mill as a physical object. Anyone who has experienced the shift from the rhythm of one life, especially that of agricultural labor, with its hard, repetitive, but often broad movements, with the constrained repetition of factory work will know why the factory and its machines evoked such a response (Goldberg, 1983: 260-261).

Strikes became more common after the end of World War I, against both working conditions and the wartime and post-war inflation that reduced the value of workers' wages. This range of factors was conducive to the expansion of precarious conditions under British occupation during the first decades of the twentieth century: twelve-hour workdays performing hard physical labour, while faced with the uncertainty of what their income would actually be worth after inflation. GDP per capita growth over this period was more strongly negative (--1.10 per cent) and inflation was sharply greater than at any other time from the late nineteenth through the mid-twentieth centuries, except for the later years of the Great Depression and World War II (Yousef, 2002: 565, 568). This was coupled with the fact that this type of work was inherently linked to the seasonal swings of the agricultural production cycle, so workers were not sure how long their jobs would last.

In summary, then, beginning in the nineteenth century, large-scale sugar and cotton production disrupted traditional agricultural and industrial commercial practices. Muhammad Ali uprooted rural populations and compelled them to work on large estates growing cotton for export, while undermining the traditional guilds and production systems in towns and cities. The British initially suppressed industrialisation in Egypt, while promoting large-scale cotton production. As efforts toward industrialisation became more widespread in the early twentieth century, these developments brought further changes to the ways Egyptians earned their living. These changes resulted in new and precarious working arrangements for Egyptians, especially in the industrial sectors. Reactions against these precarious working conditions took the form of strikes and widespread protests and rioting (Goldberg, 1983: 249-295).

2 This was also the case in India. See, for example, Ray (1979: 141). 


\section{The Development of Precarious Work in Colonial India}

New and precarious working arrangements came to define significant sectors of the Indian economy under British rule, as was the case in Egypt. India, of course, was officially part of the British Empire, and the British ruled India for nearly 200 years versus the forty years that they occupied Egypt. The significance of the structural changes the British brought to the Indian economy has been much debated (Parthasarathi, 1988, 2011). A major strand of this literature focuses on the degree to which British policies harmed traditional Indian industries. Early research that developed into this "deindustrialisation" debate includes work by Thorner (1962), Chandra (1966), and Bagchi (1976). A key feature of these analyses, especially as formulated by Bagchi, was that although the Industrial Revolution brought great change and disruption to Western Europe and its offshoots, new industries arose which were far more productive than the old industries they replaced. The argument for the case of India and other peripheral countries, however, is that no similar path to greater economic growth occurred after the first wave of industrial destruction. Indian textile industries, for example, were flourishing before the British arrived, but British trade policies resulted in the devastation of Indian industry and no improved system arose to replace it; therefore, the overall gains did not compensate for the losses.

Much has since been written in the debates surrounding Indian deindustrialisation, presenting a variety of perspectives. Roy $(2000,2006)$, for example, is critical of the stronger deindustrialisation claims. He argues that the decline of cotton spinning by hand in India from 1820 to 1880 was a straight-forward case of technological obsolescence, but one that should not be extended into a more general theory of deindustrialisation. More broadly, Roy shows that real income in manufacturing increased from 1900 to 1947 in India, thus arguing against the view that the decline in cotton spinning by hand resulted in a prolonged general reversal for Indian industry. Another framework is employed by Clingingsmith and Williamson (2004). They argue that from 1750 to 1860 the waning of the Mughal Empire's authority, increases in grain prices and industrial wages, and decreases in world prices for textiles all contributed to the deindustrialisation of India. They show that India had already gone from being a net exporter of textiles to a being a net importer by 1860 .

Taking this range of evidence into account, the story that emerges is one where Indian industry, namely cotton spinning by hand, was indeed devastated by British free trade policies in the nineteenth century. It remains debatable, however, whether this process and its consequences should be interpreted as a more general deindustrialisation of India, given that by some measures (e.g. real income in manufacturing) Indian industry was successful during the first half of the twentieth century. In the above cases, these developments are analysed at an economy-wide level. But what was the effect of these developments on the workers themselves?

In 1936-1937 two members of the economics department at the University of Madras produced a detailed survey of nine villages in South India (Thomas and Ramakrishnan, 1940). Their goal was to re-survey everything from agricultural and industrial conditions to social relations in villages that had been originally surveyed in 1916-1917. Their research yields insights into the types of changes that took place at the village level due to economic forces under British rule, painting a picture of uncertainty and flux as industries disappeared and villagers adapted to part-time working arrangements. In Guruvayur, for example, a decade before the survey was conducted oil pressing had been in a "flourishing condition" (Thomas and Ramakrishnan, 1940: 323). But when larger mills were built in Cochin and Ernakulam, thirty oil presses in Guruvayur shut down, and the remainder could not provide sufficient work for the families who depended on them (Thomas and 
Ramakrishnan, 1940: 323). Other industries, such as weaving, were also documented in the University of Madras survey as having undergone "considerable" decline due to competition with larger-scale industrial production in other regions (Thomas and Ramakrishnan, 1940: 323). Smallscale weaving establishments closed because of competition from mass-produced goods shipped into Guruvayur.

Changes to small-scale weaving and metal industries in Guruvayur brought the rise of uncertain and precarious working arrangements, as previously stable and full-time work could end due to the competitive pressures of the economic changes experienced under British rule. People adapted to these changes by earning their livelihoods through a combination of agriculture and craft production, but this was a fall-back position after full-time employment options disappeared when factories closed.

In some respects, this both supports and contrasts with the "commercialisation thesis" advanced by Roy. He argues that:

traditional industry changed not due to external competition, but due to internal competition. Internal competition was an effect of increasing market transactions. As a result of internal competition, there was a decline in less productive and less efficient organisations such as household industry, and an expansion in more efficient and more productive organisations such as units employing wage labour. This process led to a net contraction in employment and yet a rise in total and average income (Roy, 2000: 1445).

The villages surveyed by Thomas and Ramakrishnan saw a decline in small-scale industry due to competitive pressures. While at the aggregate level there could be reason to accept the desirability of replacing less productive and less efficient forms of industry with more productive and more efficient ones, it is still important to emphasise that these changes were hard on the people whose livelihoods were disrupted. Also, the evidence from Guruvayur suggests that there was not a linear development trajectory from household production to larger factories employing wage labour. Instead, what happened in Guruvayur was that competitive pressures resulted in the closing of factories that had offered relatively stable full-time wage labour jobs. The result was that people had to switch from stable full-time employment to working in agriculture while engaging in craft production on the side (Lorenzo, 1948: 18; Pandey, 1983: 111). For India as a whole, Roy finds that the move toward larger-scale production "led to a net contraction in employment and yet a rise in total and average income", but there were cases where there was a net contraction in employment along with a decrease in income (Roy, 2006: 223-224). ${ }^{3}$

The survey of Vunagatla confirms this point (Thomas and Ramakrishnan, 1940: 389-90). The number of weaver families declined from sixty-nine in 1891, to seventeen in 1901, to twelve in 1911, and to just three in 1916. This is a story of competition: in 1916 only 25 per cent of Vunagatla residents desired the rough cloth from local looms, whereas in 190695 per cent of Vunagatla residents had used this local cloth. While these changes improved the quality of life for villagers overall in the sense that they gained access to better-quality cloth, these developments disrupted the lives of the families who had made their living weaving in Vunagatla. Two of these families moved

3 See Chandavarkar (1998: 44) for further discussions of what constituted large-scale industry during this period of Indian history. 
away to work as "factory coolies" elsewhere, while those that stayed behind only continued weaving part-time, earning the rest of their livelihood working in the fields. The follow-up survey in 19361937 confirmed these trends. The evidence suggests that in some parts of India, at least, there was a decrease in full-time employment in skilled sectors along with a decrease of income in these sectors, even through the first decades of the twentieth century (Thomas and Ramakrishnan, 1940: 390).

Macro-level data also shows declines in the number of Indians working in secondary industries. Bagchi (1976: 139-140), for example, presents employment data for Gangetic Bihar; the percentage of industrial workers to the total population decreased from just over 18.5 per cent in 1809-1813 to only 8.5 percent in 1901. Roy (2006: 367) compiles adjusted census data, and similar trends are seen through the middle of the twentieth century.

The intention here is not to take sides in the deindustrialisation debate. There are facts presented on both sides of this debate that highlight the precarious nature of working arrangements in British India. While Roy, for example, is critical of the deindustrialisation claims, he also finds that conditions for workers did not necessarily improve, as seen in the cotton textile industry, where real wages were basically stagnant from 1880-1914. Unemployment in this sector contributed to the maintenance of low wages. While factors such as value-added and profitability increased from 19241940, "the transition in the [cotton weaving] industry created a space for the capitalists to operate and generally benefitted capital more than labour" (Roy, 2006: 198). Workers had to transition from traditional small-scale industries to modern industries, with wage labour replacing family labour (Roy, 2006: 221-222). The evidence from the University of Madras surveys show how this process could also move in reverse as factories closed and livelihoods became more precarious. There were winners and losers during these transitions. The cases of Guruvayur and Vunagatla suggest that the losers suffered significant changes as they lost their traditional means of earning a living and were left with more precarious working arrangements.

Chandavarkar (1998: 44) notes that there was not necessarily a clear dividing line between small-scale and large-scale industry in colonial India; both types of workplaces often produced similar products. Physically, larger-scale factories could simply be smaller sheds that had been put together, within which workers used hand-powered machines. Both large and small workplaces would produce outputs based on market fluctuations. And most importantly for the purposes of this paper, "patterns of labour use, intensive, yet flexible and casual in deployment, were common to both the formal and the informal sectors" (Chandavarkar, 1998: 44). This is the characteristic of Indian factories that highlights how precarious these working arrangements were. If workers were still guaranteed regular workweeks and steady employment, then the work would not have been as precarious, whether or not it took place in agglomerated shacks serving as factories, and whether or not the work was performed with simple hand-powered machines versus more complex instruments. (See Joshi, 2005: 318, for a modern example.)

Colonial British statistical sources also highlight how some of the precarious aspects of industrial employment at this time were due to market fluctuations. From 1903-1904, for example, cotton prices increased, which "made profitable business difficult, so that several mills either closed or worked short time." The following year, however, the price of raw cotton fell and "all the spindles had to be brought into full use" (Statistics of British India, 1908: 21). Clearly these were not stable working conditions, as employment opportunities were at the whim of the market. There was, however, some governmental oversight of working conditions. For example, the British kept statistics on employers who violated the safety regulations of the Factory Act (Statistics of British India, 
1909: 29; similar records exist for other years). Still, these convictions were few in number compared to the fatal and serious accidents that were recorded (Statistics of British India, 1909: 28). Also, these official sources highlight the differences between full-time and seasonal industrial work. In 1929, for example, it was reported that "The provision of housing accommodation is adequate in the larger of the perennial factories, but no effort has yet been made to improve the lot of the seasonal worker" (Report on the Administration of the Indian Factories Act, 1929: 2). Similarly, "Strict conformity with the rules regarding hours of employment and holidays is observed by the perennial concerns; but the same cannot be said of the seasonal factories" (Report on the Administration of the Indian Factories Act, 1929: 9).

As in the Egyptian case, the transition from rural agricultural lifestyles to urban industrial living and working environments had wide-ranging effects on the people involved. Roy (2006: 242) presents samples of wage data from large-scale industries in India, from 1900 to 1944. Average annual incomes increased for Indian industrial workers over this period. Wages more than doubled in Bombay cotton textile mills, increased 2.5 times in Ahmedabad cotton textile mills, and increased 115 per cent in Calcutta jute mills. These averages hide other trends in workers' quality of life, however. Roy (2006: 241) argues that those at the top of the industrial wage hierarchy "could usually enjoy a lifestyle better and more secure than that in the village". Most industrial workers in British India, however, "earned an income too little or too insecure to think of growing roots in the city and giving up connections with the land" (Roy, 2006: 242, emphasis added; see also Lorenzo, 1948: 22 23). This aligns with the analysis of the Egyptian "peasants in workers' clothing" discussed above. Still, Roy points out that during the interwar period Indian urban workers' wages were two to three times those of agricultural workers, and industrial workers were also less subject to famines than were agricultural workers. Additionally, as was seen in Egypt, old behaviours and social patterns (such as caste divisions) followed Indian workers from the countryside to the city, and this hindered both factory discipline and class-based labour organisation (Roy, 2006: 243). ${ }^{4}$

Writing one year into Indian independence, Lorenzo (1948: 24) argued that the industrial workforce accounted for such a small portion of total labour in India that the concept of an Indian industrial working class was a "myth". "A large majority of the industrial workers are misfits and floating farm hands which feed industrial establishments at irregular intervals and give no stability to industrial labour power" (Lorenzo, 1948: 24-25; emphasis added). Lorenzo (1948: 26) also argued that, on average, "not more than 20 per cent [of Indian industrial workers] are permanent residents [in industrial urban settings], whilst 80 percent constitute the floating fund of rural workers employed in factory industries only temporarily". In these mid-century industrial settings, working conditions were "hot, close, crowded and noisy", and living conditions for industrial workers had "no sunshine, no clean air to breathe, not enough water to wash in, no sanitary conveniences, no room for comfortable sleeping and decent living" (Modi, 1952: 187-188, quoted in Myers, 1958: 43). These conditions had physical effects on Indian industrial workers. Urban health statistics from 1938-1940 show higher death rates in Indian cities than in rural areas. "This is undoubtedly due to smoke, noise, overcrowding and the presence of poverty" in cities (Sharma, 1948: 236). Still, data on strikes in India from 1921 to 1947 show that most strikes were over wages. Forty-two per cent of Indian strikes in 1921 were related to wages. This figure peaked at 67 per cent of strikes in 1933, and fell to

\footnotetext{
${ }^{4}$ See also Lorenzo (1948: 25): "His [Indian industrial workers'] early upbringing in the rural atmosphere makes it difficult for him to adapt to a purely industrial milieu."
} 
31 per cent of strikes by 1947. Bonuses, personnel issues, disputes over leave time and hours of work, or other demands tended to account for smaller percentages of motivations behind strikes (Chakraborty, 1969: 144). Of course, workers faced brutal working and living conditions during periods of early industrialisation in other parts of the world, from Lancashire to Massachusetts. Strikes and organised resistance were features of industrialisation in these places, just as they were in colonial Egypt and India. But the historical development of industrial employment in the West moved toward standardised working and living conditions, schedules and expectations, whereas industrial employment in colonial Egypt and India was defined by the insecurity and contingency that Kalleberg (2009: 6-8) ascribes to precarious working arrangements in the post-Bretton Woods era.

\section{International Context and Concluding Remarks}

There are two connected, overarching features that shape the context in which Egypt and India experienced some development of large-scale industry during the late nineteenth and early twentieth centuries: namely, their being part of the British Empire and their location in what is today referred to as the Global South. Imperialism shaped the development of industry in these countries, and the related rise of new, precarious employment relations had a different trajectory over the course of the twentieth century in the Global South compared to the Global North. ${ }^{5}$

The Egyptian and Indian cases described above highlight how employment became more precarious as modern industries developed under British imperial rule. ${ }^{6}$ The international, imperial context defines important parts of these developments, as, for example, the large-scale textile production that occurred in India took place in factories designed along the lines of similar operations in England. British-imposed free trade shaped these developments, but the imperial context also explains the lack of broader industrialisation in Egypt, for example, where industrial production was mainly encouraged for the processing of perishable goods such as sugar cane, while the economy overall was directed toward producing raw cotton for British mills. Thus the industrialisation that took place under British rule was shaped by the competing forces of free trade and the active management of colonial economies, which secured British dominance in India and Egypt.

The positions these countries held in the British imperial system shaped the trajectory their industrial development followed. Modern industrial production had been developing in "core" countries such Britain and the United States for decades before the rise of similarly scaled production in Egypt and India. While the changes in employment structures brought by industrialisation did lead to new and precarious work relationships in the West (Jacoby, 2004), by the early twentieth century stronger regulation and the rise of "progressive" reform movements had increased the stability of these jobs. Though British India had a series of Factory Acts promoting workplace safety, the

\footnotetext{
5 In the May 2016 special issue of the Global Labour Journal the relevance of the "precarious work" framework is highlighted for the Global South. Scully (2016: 189), for example, notes that "many of the features that Standing associates with the contemporary 'precariat' have long been widespread among Southern workers", and Standing (2016: 189) argues that the precariat is "a global, not 'Eurocentric' or 'Northern' phenomenon".

${ }^{6}$ For an analysis of the spread of trade and power relations under British imperialism in a World Systems framework, see, for example, Arrighi (2010: 169).
} 
structure of industrial employment remained precarious. Part of the explanation for these different trends can be connected to a "reserve army of labour" story. As Britain and the U.S. completed their transitions to urbanised industrial economies, workers demanded more stable labouring arrangements. But as long as factories in India and Egypt could rely on flows of workers from villages to factories, employers were under less pressure to offer more stable jobs. That is not to say that labour unrest was not an important feature of industrial development in both the Global South and North (Silver, 2003), but employers faced less pressure to change when new supplies of cheap and less-skilled labour were readily available.

It is significant that the timing of industrialisation (to the extent that it occurred) was different in the Global North than in the Global South. By the height of the colonial era workers in the North were more likely to have secured stable employment, whereas industrial workers in the South experienced the decline of older social and economic systems and the rise of precarious work. Extending Kalleberg's framework further back in time suggests a pendulum-like swing back toward precariousness in the North. In the South, the history of industrial development offers the insight that industrialisation does not necessarily lead to stable work. Many of the analyses of the post-war "golden age" in the North praise the manufacturing jobs on offer in mid-twentieth-century America and Britain. But it was the labour-capital relations of that time that limited precarity, not the jobs in and of themselves. To make this case more concretely in a global context across the twentieth and early twenty-first centuries requires more space than is available here. Davis's $(2004,2006)$ focus on the overall precarity defining the lives of many in the South in recent decades is part of this story, and again there is more room for bringing "informal" economic activity into this analysis, as people fill the gaps in precarious labour arrangements through informal channels. ${ }^{7}$ But Davis's (2006: 178) "informal proletariat" does not overlap entirely with precarious workers, who might have more formal employment but still be lacking stability or security. Informal employment is a more severe situation in that it precludes contracts, rights and regulations, which can still be part of precarious employment relations (Breman, 2003).

Many of the developments that took place in industrialising colonial Egypt and India had parallels in industrialising Western Europe: peasants leaving village life to work in factories, inhumane industrial working and living conditions, strikes and protests against the precariousness of unstable working conditions. Marx, for one, documents all of these factors in nineteenth century Europe, just as the evidence analysed above demonstrates their occurrence in colonial Egypt and India. Pandey (1983: 119) rightfully argues that the "common objection that all of this was inevitable, that older, less efficient modes of production must necessarily give way to more rational and modern ones, is deficient", especially in non-Western contexts. The uncertainty and insecurity that make up a major part of Kalleberg's definition of precarious work also describe the experiences of workers during these transitions in Egypt and India. Again, this highlights the enduring precarity facing workers during both the historical rise of industrial employment and the decline of post-war labour arrangements in the North. This does not have to mean that the "precariat" forms a new, identifiable global class of workers (Bremen, 2013). Instead, recognising that work that has been viewed as being especially stable (post-war industrial jobs in the North, for example) is a historical anomaly points

\footnotetext{
7 An example of another type of employment decision is presented in Blattman and Dercon (2012), who find high turnover at Ethiopian factories, when workers choose to return to the informal sector rather than be subjected to undesirable industrial working conditions.
} 
toward broader trends in capitalist development that tend to be destabilising.

Pandey (1983: 119) is correct to note that the "common objection that all of this was inevitable ... fails to take account of the particularities of the colonial experience."

This is where the very slow growth of modern industry created special problems, in India as in so many other Asian and African countries. There was a large-scale disruption of forms, without a real transformation. The handicraftsmen of old, like vast numbers of the poorer peasants and agricultural labourers, found their means of livelihood in jeopardy: but their links with their rural homes were not completely severed. What was in western Europe a relatively short-lived if traumatic period of change became in the sub-continent and elsewhere a chronic condition (Pandey, 1983: 119-120).

That is the main argument of this paper. While precarious working conditions defined aspects of nineteenth-century industrialisation in the West, it was a period of transition that led to more stable working conditions and the "golden age" of post-war capitalism. Other parts of the world did not experience this development trajectory. While the "deindustrialisation" debate continues, the historical record shows that the industrialisation that did occur in colonial Egypt and India was highly disruptive to existing social and economic systems. These changes resulted in the creation of working arrangements that were unstable, insecure, and contingent - in a word, precarious.

\section{REFERENCES}

Agarwala, R. (2013) Informal Labor, Formal Politics, and Dignified Discontent in India. Cambridge: Cambridge University Press.

Arrighi, G. (2010) The Long Twentieth Century: Money, Power and the Origins of our Times. London: Verso.

Baer, G. (1964) Egyptian Guilds in Modern Times. Jerusalem: Israel Oriental Society.

Bagchi, A.K. (1976) De-industrialisation in India in the Nineteenth Century: Some Theoretical Implications. Journal of Development Studies, 12(2): 135-164.

Blattman, C. and S. Dercon (2012) More Sweatshops for Africa? Pilot Results from an Experimental Study of Industrial Labor in Ethiopia. International Growth Centre Working Paper F-5006-ETH-1. Available online at https://www.thejgc.org/wp-content/uploads/2012/03/Blattman-Dercon-2012-Working-Paper.pdf.

Breman, J. (2003) The Labouring Poor in India: Patterns of Exploitation, Subordination, and Exclusion. Delhi: Oxford University Press.

Breman, J. (2013) A Bogus Concept? New Left Review, 84: 130-138.

Broad, D. (2000) The Periodic Casualization of Work: The Informal Economy, Casual Labor and the Longue Durée. In Informalization: Process and Structure, edited by F. Tabak and A. Crichlow, A. Baltimore: Johns Hopkins University Press.

Chakraborty, P. (1969) Strikes and Morale in Industry in India and her Principal States. Calcutta: Eastern Law House.

Chandavarkar, R. (1998) Imperial Power and Popular Politics: Class, Resistance and the State in India, c. 1850-1950. Cambridge: Cambridge University Press.

Chandra, B. (1966) The Rise and Growth of Economic Nationalism in India. New Delhi: Peoples' Publishing House.

Clingingsmith, D. and J.G. Williamson (2004) India's De-industrialization under British Rule: New Ideas, New Evidence. NBER Working Paper No. 10586. Available online at http://www.nber.org/papers/w10586.pdf. 
Davis, M. (2004) Planet of Slums. New Left Review, 26: 5-36.

Davis, M. (2006) Planet of Slums. Second edition. London: Verso.

Goldberg, E.J. (1983) Tinker, Tailor, and Textile Worker: Class and Politics in Egypt, 1930-1954. Unpublished PhD thesis, University of California, Berkeley.

Jacoby, S.M. (2004) Employing Bureaucracy: Managers, Unions, and the Transformation of Work in the 20th Century. Mahwah, N.J.: Lawrence Erlbaum Associates Publishers.

Joshi, C. (2005) Lost Worlds: Indian Labour and its Forgotten Histories. London: Anthem Press.

Kalleberg, A.L. (2009) Precarious Work, Insecure Workers: Employment Relations in Transition. American Sociological Review, 74(1): 1-22.

Lorenzo, A.M. (1948) Indian Labour in Primary Industries. Lucknow: Universal Publishers.

Mansfield, P. (1971) The British in Egypt. New York: Holt, Rinehart and Winston.

Marx, K. (1976) Capital: A Critique of Political Economy, Volume One. London: Lawrence \& Wishart.

Myers, C.A. (1958) Labor Problems in the Industrialization of India. Cambridge, M.A.: Harvard University Press.

Owen, E.R.J. (1969) Cotton and the Egyptian Economy, 1820-1914: A Study in Trade and Development. Oxford: Clarendon Press.

Pandey, G. (1983) Economic Dislocation in Nineteenth Century Uttar Pradesh: Some Implications of the Decline of Artisanal Industry in Colonial India. In Rural South Asia: Linkages, Change and Development, edited by P. Robb. London: Curzon Press.

Panza L. and J.G. Williamson (2013) Did Muhammad Ali Foster Industrialization in Early 19th Century Egypt? Centre for Economic Policy Research (CEPR) Discussion Paper No. 9363. Available online at http://www.nber.org/papers/w9363.pdf.

Parthasarathi, P. (2011) Why Europe Grew Rich and Asia Did Not: Global Economic Divergence, 1600-1850. Cambridge: Cambridge University Press.

Parthasarathi, P. (1998) Rethinking Wages and Competitiveness in the Eighteenth Century: Britain and South India. Past \& Present, 158(1): 79-109.

Ray, R.K. (1979) Industrialization in India: Growth and Conflict in the Private Corporate Sector, 1914-47. Delhi: Oxford University Press.

Report on the Administration of the Indian Factories Act 1911 (Act XII of 1911), as modified up to the 1st June 1926, in the Central Provinces and Berar for the year 1928 (1929). Nagpur.

Roy, T. (2000) De-industrialisation: Alternative View. Economic and Political Weekly, 35(17): 1442-1447.

Roy, T. (2006) The Economic History of India, 1857-1947. New Delhi: Oxford University Press.

Scully, B. (2016) Precarity North and South: A Southern Critique of Guy Standing. Global Labour Journal, 7(2): $160-173$.

Sharma, T.R. (1948) Location of Industries in India. Bombay: Hind Kitabs.

Silver, B.J. (2003) Forces of Labor: Workers' Movements and Globalization since 1870. Cambridge: Cambridge University Press.

Standing, G. (2016) The Precariat, Class and Progressive Politics: A Response. Global Labour Journal, 7(2): 189_ 200.

Statistics of British India, for 1906-07 and Preceding Years, Part I, Industrial, including Statistics relating to Factories, Mills, Mines, etc. (1908) Compiled in the Office of the Director General of Commercial Intelligence, India. Calcutta. 
Statistics of British India, for 1907-08 and Preceding Years, Part I, Industrial, including Statistics relating to Factories, Mills, Mines, etc. (1909) Compiled in the Office of the Director General of Commercial Intelligence, India. Calcutta.

Tabak, F. and A. Crichlow (eds.) (2000) Informalization: Process and Structure. Baltimore: Johns Hopkins University Press.

Thomas, P.J. and K.C. Ramakrishnan (eds.) (1940) Some South Indian Villages: A Resurvey. Madras: University of Madras.

Thorner, D. (1962) De-industrialization in India, 1881-1931. In Land and Labour in India, edited by D. Thorner and A. Thorner. Bombay: Asia Publishing House.

Van der Linden, M. (2003) Transnational Labour History: Explorations. Aldershot: Ashgate.

\section{BIOGRAPHICAL NOTE}

PETER BENT is a PhD student in Economics at the University of Massachusetts, Amherst. His

dissertation studies the interactions between governments and markets during financial crises at the turn of the twentieth century. [Email: pbent@umass.edu] 